\title{
THE IMPACT OF EMPLOYEE SATISFACTION ON THE TOURIST SATISFACTION WITH THE SERVICES OF SPA TOURISM
}

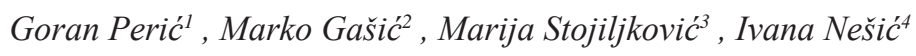

*Corresponding author E-mail: goran.peric@vpskp.edu.rs

\begin{abstract}
A R T I C LE INFO
A B S T R A C T

Original Article

Received: 01 February 2018

The quality of employees' work in the tourism industry depends primarily on their job satisfaction. This has Accepted: 04 May 2018 directed the subject of the research in this paper to examine the impact of employee satisfaction on tourist satisfaction doi:10.5937/ekoPolj1802617P

UDC 339.13.017:338.48-5

Keywords:

employee satisfaction, quality of service, tourist satisfaction, spa tourism.

JEL:L83, J28, M30 with the services of spa tourism in the Republic of Serbia. Research was conducted using the survey method, the questionnaire technique, in Lukovska Spa, based on a sample of 125 respondents, of which 55 were employees and 70 tourists / guests in hotels "Jelak" and "Kopaonik". The most important finding of the research is related to the correlation between the employee satisfaction and the tourist satisfaction with the quality of service in Lukovska Spa, which confirmed the hypothesis of the direct and positive impact of employee satisfaction on the tourist satisfaction with the quality of services. Employee satisfaction has a positive impact on the quality of the service, which directly affects the tourist satisfaction with the quality of the services provided.
\end{abstract}

(C) 2018 EA. All rights reserved.

\section{Introduction}

The aim of every business organisation is to be successful and to achieve longterm progress. The modern market and the business environment are characterized by turbulence and unpredictable changes which cause organizations to be flexible, adaptable and innovative in order to maintain its competitiveness and to survive on the market. In order to succeed, a strong and positive relationship between employees and the organization is necessary. Employees are of great importance and they have a

1 Goran Perić, Ph.D. Student, University of Kragujevac, Faculty of Hotel Management and Tourism, Vojvođanska Street, 36210 Vrnjci Spa, Serbia, phone number: +381 652912 980, e-mail: goran.peric@vpskp.edu.rs, ORCID ID (http://orcid.org/0000-0001-7954-7663)

2 Marko Gašić, Assistant, Business School of Applied Studies, Kralja Petra I, No.70, 18420 Blace, Serbia, phone number +381 637629 075; e-mail: gasicmarko@yahoo.com

3 Marija Stojiljković, MSc, Teacher of skills, Business School of Applied Studies, Kralja Petra I, No.70, 18420 Blace, Serbia, phone number: +381 62271 456; e-mail: m.stojiljkovic@yahoo.com

4 Ivana Nešić, English language teacher, Business School of Applied Studies, Serbia, Kralja Petra I, No.70, 18420 Blace, Serbia, phone number+381 641666 157, email: ivanadjokic@vpskp.edu.rs 
crucial role in the process of production; they introduce changes and innovations, they create additional value and they increase business efficiency, and thus the initiation of future organization performance. When employees are satisfied, they are motivated to fulfill their business tasks and to achieve the goals of the organization, which forms the basis for the progress and success of the organization. This is particularly evident in the service sector, such as tourism, in which consumer loyalty, their decisions about purchases and repetition of purchases, and their future recommendations depend on their perception and satisfaction, which employees influence directly or indirectly.

In the spa tourism organizations, tourists and employees are referred to mutual cooperation during the realization of the service, and the success of this interaction depends largely on the capacities, knowledge and skills of employees in the provision of services (Perić et al., 2015). The quality of employee performance in the tourism industry depends primarily on their job satisfaction. Employees who are not sufficiently professional and dissatisfied can have a long-term negative impact on the quality of services and products and, therefore, on the satisfaction of consumers in tourism (Vrtiprah, Sladoljev, 2012). The assumption about the impact of employee satisfaction on consumer satisfaction in the service sector was confirmed by the results of numerous empirical researches (Harter et al., 2002; Koys, 2003; Wangenheim et al., 2007; Yee, Yeung, Cheng, 2008; Jung, Yoon, 2013) which indicate the significant impact of employee satisfaction on creating and maintaining customer satisfaction and loyalty, resulting in an increase in sale and profitability of the organization. Even though there are studies in domestic, expert and scientific literature that examined various factors of tourist satisfaction and employee satisfaction in the tourism sector (Laškarin Ažić, 2017; González, Comesaña, Brea, 2007; Sekulić, 2016; Choi, Chu, 2000), there is a significantly lower number of studies which investigated the impacts and effects of employee satisfaction on customer satisfaction (Jeon, Choi, 2012; Spinelli, Canavos, 2000). This has directed the subject of the research in this paper to examine the impact of employee satisfaction on the tourist satisfaction with the services of spa tourism in the Republic of Serbia. In order to achieve and maintain competitiveness, organizations in the tourism industry use different strategies, which is why it is important to examine whether and to what extent employee satisfaction affects customer satisfaction with the quality of services provided, in order to formulate an effective strategy and allocate significant resources to increase employee satisfaction.

The main goal of this research is to identify the impact of employee satisfaction on the tourist satisfaction with services in spa tourism. From the aspect of this research, an explanation of the relationship between employee satisfaction and satisfaction of service users in organizations of spa tourism is of primary importance, which is why the overall goal is realized through the following specific goals:

- to review the literature and studies in the area of employee satisfaction and tourist satisfaction; 
- to analyze the impact of different organizational factors (relationships between management and employees, salaries and rewards, interpersonal relationships, education and training courses, working environment) on employee satisfaction in spa organizations,

- to identify the main factors of employee satisfaction;

- to identify the main factors of customer satisfaction with the quality of services;

- to analyze the impact of employee satisfaction on the quality of services in spa organizations;

- to analyze the impact of the quality of services on tourist satisfaction in spa tourism;

- to examine whether there are differences in employee satisfaction with regard to socio-demographic variables (gender, level of education, working internship);

- to examine whether there are differences in tourist satisfaction with the quality of services, in relation to socio-demographic variables (gender, level of education, age).

Spa tourism is an important segment of tourism of specific interests, in which the desire to improve wellbeing and beauty, as well as to prevent diseases in the spa tourist resort are the primary motives for travel (UNWTO, 2012:16). This type of tourism in Serbia has a long and rich tradition, and due to the large contribution of spa tourism in the tourism traffic in our country, Serbia is also known as the "country of spas" (Perić et al., 2017). In the past decade, wellness and health tourism and recreational tourism within the tourism industry have become one of the fastest growing segments and a very profitable market niche. Considering the fact that Serbia has a great but underused potential for the development of spa tourism, and the fact that the degree of evaluation of spa tourism value lags behind the real possibilities (Topalović, 2013), it is important to find an adequate strategy that will effectively increase the number of tourists in spa tourism, regardless of whether it is a large number of visitors or longer stays of tourists in a spa destination. Identification of factors that affect tourist satisfaction with the quality of services in spa organizations and the impact of employee satisfaction on the quality of spa services enables the management of spa tourism organizations to obtain a better insight into the relationship between employee satisfaction and the tourist satisfaction with the quality of the provided services and to use this information to customize their strategy so that it meets the wants and needs of their segment of the tourism market.

\section{Literature review}

Theories, approaches and concepts on the behavior and employee motivation and employee satisfaction were created as a response to the managerial challenge to find a way to manage the behavior of people in organizations, with the aim of achieving the goals of the organization (Miljković, 2007). Leadership strategies were built on this challenge. The task of the manager is, depending on the specific circumstances, to choose 
and apply appropriate strategies that will ensure the desirable behavior of employees and the achievement of both personal goals of the employees and the goals and tasks of the organization. According to one of the first definitions of this term, employee satisfaction is seen as a combination of psychological factors and environmental factors that affect employee satisfaction with his or her performance (Pavlović, Marković 2014). Locke (1976:1297) defines employee satisfaction as a pleasant or positive emotional state which is the result of performing a job or a whole work experience. Davis and Nestrom (1985:109) see employee satisfaction as a relatively simple concept, which is a combination of positive and negative feelings that an employee has about his job. According to these authors, job satisfaction is closely linked to the behavior of an employee in the workplace, and how much his expectations match the real rewards that he receives through his work. This view is also supported by Statt (2004:78), who states that the employee satisfaction is manifested through the extent to which the employee is satisfied with the rewards he receives for performing his job. Lease (1998) points out that employees with higher levels of satisfaction have lower levels of being absent from work, they are more productive, more dedicated to the organization and its goals, and generally more satisfied with their lives. Sagger, Rafat and Agarwal (2012) emphasis that organizational factors impact the levels of employee satisfaction. Employees spend a lot of time at work and, therefore, it is logical that most factors from the organizational environment will influence employee satisfaction. Employee satisfaction can be improved through management of organizational factors, such as: organization development, the rewards system, promotion and career development, work environment, relationships with management, teamwork, general work satisfaction etc. (Đokić, Pepur, Arnerić, 2015:55). The results of research carried out by Meyer (1999) confirm that the level of employee satisfaction is related to employees' commitment, which means that employee satisfaction has a direct impact on organizational goals and performance. This is especially evident in the service sector, such as tourism and hotel industry, where the focus of quality is on services provided by employees and largely depends on their knowledge, skills, appearance and behavior towards tourists. Due to the intangibility of services in tourism, consumers can use a very small number of options for evaluating their overall experience, where employees' courtesy, service and professionalism are the most important tangible indicators of service quality. Therefore, the quality of contact between employees and tourists is one of the basic factors that determine the level of tourist satisfaction with the quality of the services provided.

The tourist satisfaction can be viewed as an evaluation of the user's experience with the provided services, whereby it is necessary that the tourist satisfaction with the service is rated at least as good as expected (Hunt, 1977). As Oliver (1980) further explains, when an individual experiences the service and compares the experience with the expectations, customer satisfaction or dissatisfaction arise as results. Therefore, tourist satisfaction is based on real experiences and their perception of the quality of the provided service. The quality of services consists of two dimensions: technical and functional quality, whereby technical quality refers to what the consumer actually receives from the service provided, 
whereas the functional quality refers to the ways in which the consumer receives the service (Dinić, Vranješ, Gašević, 2014). Grönroos (1984) claims that the technical aspect of service quality should not be neglected, but he also emphasizes that the functional quality is the most important factor in the evaluation of service quality. In this sense, the contact of tourists with the employees in the tourism industry imposes itself as a crucial determinant of the functional quality of the service.

From the perspective of the previously mentioned research findings on the impact of employee satisfaction on their work performance and commitment to the job, it can be concluded that there is a direct impact of employee satisfaction on tourist satisfaction with the quality of service. The findings of numerous studies point to the accuracy of the assumption that the correlation between employee satisfaction and consumer satisfaction in the service sector is present. One of the earliest studies, carried out by Schneider and Bowen (1985), showed that satisfied employees express greater initiative, which further positively reflects on increasing consumer satisfaction with the quality of service. The findings of the longitudinal study which was carried out by Bernhart, Dontu and Kenneth (2000), in order to examine the relationship between employee satisfaction, consumer satisfaction and the profitability of fast food restaurants chain, have shown that there is a positive and significant relation between consumer satisfaction and employee satisfaction, until a significant relationship between consumer satisfaction and restaurant performance, as well as the impact of employee satisfaction on the work performance, has been revealed. Spinelli and Canvos (2000) conducted a research in six hotels in which 600 guests and 240 employees participated and they determined a statistical relation of employee satisfaction and guest satisfaction. A metaanalysis of 7,937 business units in 36 companies, the aim of which was to examine the impact of employee satisfaction on customer satisfaction, profitability, productivity and employee fluctuation, has shown that employee satisfaction has a significant impact on all mentioned variables (Harter, Schmidt, Hayes, 2002). Chi and Gursoy (2009) conducted a survey in order to examine the relationships between employee satisfaction and tourist satisfaction in 150 three and four star hotels, and the findings of the research are in accordance with the results of the previously mentioned studies. It has been confirmed that a direct relation between the employee satisfaction and the satisfaction of the tourists/hotel guests was established. Findings of this kind of empirical studies show that satisfied employees are highly motivated to provide quality service to consumers, and suggest that employee satisfaction should be of primary importance to the management of tourist organizations, because if the organization takes care of employees, employees will then adequately take care of tourists.

\section{Methodology}

The survey method, the questionnaire technique, was conducted for the collection of primary data. This technique includes the research method through which data is collected systematically from a group of respondents in the form of personal opinions. The main hypothesis of this research is that employee satisfaction positively influences 
tourist satisfaction with the services in spa tourism. Accordingly, two additional hypotheses arise:

- $\quad$ H1: Employee satisfaction has a positive impact on the quality of services in organizations of spa tourism

- H2: The quality of the service has a positive impact on the tourist satisfaction in spa tourism.

The questionnaire as a research technique was chosen for the collection of primary data based on numerous studies which dealt with research on the impact of employee satisfaction on tourist or consumer satisfaction in the service sector (Chi, Gursoy, 2009; Harter, Schmidt, Hayes, 2002; Yee, Yeung, Cheng, 2008; Jung, Yoon, 2013; Spinelli, Canvos, 2000). Two questionnaires were designed. The first questionnaire was designed to examine the employee satisfaction, while the second questionnaire was designed to examine the tourist satisfaction with the quality of services in spa tourism. Both questionnaires consist of questions about the socio-demographic characteristics of the respondents in the first part, while the second part of the questionnaire contains statements related to various factors of satisfaction of employees/tourists, followed by variants of respondents' responses based on a five-point Likert scale (from $1=$ strongly disagree to $5=$ completely agree). The factors of employee satisfaction (management and employee relations, wage and rewards, interpersonal relations, training courses, work environment) were selected based on a review of literature on different models and key employee satisfaction factors (Lawler, Porter, 1967; Christen et al., 2006; Singh, Jain, 2013; Đokić, Pepur, Arnerić, 2015). Taking into account the specifics of tourism and hotel industry business, factors of tourist satisfaction with the quality of service which are defined are (Spinelli, Canavos, 2000): the quality of check-in at the reception desk; tidiness and cleanliness of the room; quality and choice of food in the hotel restaurant; quality of wellness / spa and medical treatments, tidiness and cleanliness of the hotel; professionalism and hospitality of the hotel employees; overall quality of services in the hotel.

The survey was carried out during January, 2018 in Lukovska spa, in hotels "Kopaonik" and "Jelak", on a sample of 125 respondents (55 employees in hotels and 70 tourists). The questionnaires were filled out by employees during their working hours and they were given guidelines how to fill in the questionnaires. The questionnaire was filled in by 55 employess, that it $61 \%$, from a total of 90 employees in both hotels. Questionnaires were handed out to guests in the hotel lobby, after lunch, that is, dinner. The questionnaire was filled in by 70 guests, which is $60 \%$ of the total number of guests staying at hotels "Kopaonik" and "Jelak" during the period. The data was processed by quantitative analysis. In the statistical data processing, optimal statistical methods for testing hypotheses were applied:

- Descriptive statistical measures were used for sample description,

- Variability measures - the mean (M) and standard deviation (SD) were used to display the scores on the questionnaires. 
- Pearson's linear correlation coefficient was used to test the correlation between variables.

- Analysis of ANOVA variance and significance (F) was used to show the significance of differences between the scores on individual variables.

Statistical analyses were carried out within the statistical package SPSS 20.0.

\section{Research results and discussions}

Statistical processing of the data comprises a sample of 125 respondents, which is divided into two subgroups, one of which are hotel employees $(\mathrm{N}=55)$ and a second sub-sample are hotel tourists / guests $(\mathrm{N}=70)$.

Table 1. Sample structure

\begin{tabular}{|c|c|c|c|c|}
\hline $\begin{array}{l}\text { Category of } \\
\text { respondents }\end{array}$ & $\begin{array}{l}\text { Demographic } \\
\text { variables }\end{array}$ & $\begin{array}{c}\text { Category of } \\
\text { variables }\end{array}$ & $\mathbf{F}$ & $\%$ \\
\hline \multirow{10}{*}{ Employees } & \multirow{2}{*}{ Gender } & Male & 23 & 41.8 \\
\hline & & Female & 32 & 58.2 \\
\hline & \multirow{4}{*}{ Work experience } & Up to 5 years & 10 & 18.2 \\
\hline & & $6-10$ years & 14 & 25.5 \\
\hline & & $10-20$ years & 16 & 29.1 \\
\hline & & Over 20 years & 15 & 27.3 \\
\hline & \multirow{4}{*}{ Education } & Secondary & 33 & 60.0 \\
\hline & & College & 11 & 20.0 \\
\hline & & University degree & 9 & 16.4 \\
\hline & & Master/PhD & 2 & 3.6 \\
\hline \multirow{11}{*}{ Tourists } & \multirow{2}{*}{ Gender } & Male & 39 & 55.7 \\
\hline & & Female & 31 & 43.3 \\
\hline & \multirow{5}{*}{ Age } & Up to 29 years & 8 & 11.4 \\
\hline & & 30- 39 years & 18 & 25.7 \\
\hline & & $40-49$ years & 5 & 7.1 \\
\hline & & $50-59$ years & 23 & 32.9 \\
\hline & & Over 20 years & 16 & 22.9 \\
\hline & \multirow{4}{*}{ Education } & Secondary & 18 & 25.7 \\
\hline & & College & 20 & 28.6 \\
\hline & & University degree & 24 & 34.3 \\
\hline & & Master/PhD & 8 & 11.4 \\
\hline
\end{tabular}

Source: Author's calculation based on SPSS 20.0

In analyzing the research results, we will start from the specific research goals. First, we will comment on the impact of different organizational factors on the employee satisfaction in spa organizations, as illustrated in Table 2. 
Table 2. Key factors of employee satisfaction

\begin{tabular}{|l|c|c|c|c|c|}
\hline \multicolumn{1}{|c|}{$\begin{array}{c}\text { Claims about factor of employee } \\
\text { satisfaction }\end{array}$} & N & Min & Max & Mean & $\begin{array}{c}\text { Standard } \\
\text { deviation }\end{array}$ \\
\hline $\begin{array}{l}\text { Management has a good } \\
\text { communication with employees }\end{array}$ & 55 & 2.00 & 5.00 & 4.3636 & .77850 \\
\hline $\begin{array}{l}\text { Management includes employees in the } \\
\text { decision-making process }\end{array}$ & 55 & 1.00 & 5.00 & 4.1273 & .84007 \\
\hline Provided training courses & 55 & 1.00 & 5.00 & $\mathbf{4 . 4 0 0 0}$ & .85201 \\
\hline Salary satisfaction & 55 & 2.00 & 5.00 & 4.2727 & .80403 \\
\hline $\begin{array}{l}\text { Satisfaction with the working } \\
\text { environment }\end{array}$ & 55 & 3.00 & 5.00 & $\mathbf{4 . 4 7 2 7}$ & .53936 \\
\hline Reward system & 55 & 2.00 & 5.00 & 4.2000 & .84765 \\
\hline Good relationships among employees & 55 & 2.00 & 5.00 & $\mathbf{4 . 4 3 6 4}$ & .68755 \\
\hline Overall job satisfaction & 55 & 3.00 & 5.00 & $\mathbf{4 . 6 5 4 5}$ & .51705 \\
\hline
\end{tabular}

Source: Author's calculation based of SPSS 20.0

The first important result is related to the fact that the overall job satisfaction has the highest score (4.65). It is interesting that overall job satisfaction is greater than any individual factor, indicating that there is either another important factor affecting job satisfaction, or it is that when a favorable general impression is disassembled to individual elements, better insight is obtained and a more realistic assessment of different aspects of the job. It can also be noted that the employees are satisfied with all aspects of the job because the scores on all factors have a value over 4 . Factors employees are the most satisfied with are: satisfaction with the working environment (4.47), good relationships among employees (4.436), and job training course (4.40). In one of the previous studies in which employees of the hotels "Kopanik" and "Jelak" participated, the relations between employees and the provided training were evaluated worse, that is, they were ranked with the following scores: 3.89 and 4.00, whereas the satisfaction levels with the working environment were identical with the obtained results in this research (Perić, 2014). Greater employee satisfaction in the aforementioned is the result of the hotel management efforts to improve factors which influence employee satisfaction.

The following table of variance analysis shows statistically significant differences in terms of demographic variables of gender and years of working experience. There are no statistically significant differences in relation to the education level because the respondents have the same point of view for the given questions. 
Table 3. Display of statistically significant differences in individual satisfaction factors in relation to demographic variables

\begin{tabular}{|c|c|c|c|c|c|}
\hline Factor & Gender & Mean & $\begin{array}{l}\text { Standard } \\
\text { deviation }\end{array}$ & $\mathbf{F}$ & $\begin{array}{c}\text { Statistical } \\
\text { significance }\end{array}$ \\
\hline \multirow{2}{*}{$\begin{array}{l}\text { Management includes } \\
\text { employees in the decision- } \\
\text { making process }\end{array}$} & M & 4.39 & 0.66 & \multirow{2}{*}{4.131} & \multirow{2}{*}{.047} \\
\hline & $\mathrm{F}$ & 3.94 & 0.91 & & \\
\hline Factor & $\begin{array}{c}\text { Work } \\
\text { experience }\end{array}$ & Mean & $\begin{array}{l}\text { Standard } \\
\text { deviation }\end{array}$ & $\mathbf{F}$ & $\begin{array}{c}\text { Statistical } \\
\text { significance }\end{array}$ \\
\hline \multirow{4}{*}{ Salary satisfaction } & Up to 5 & 3.60 & 1.07 & \multirow{4}{*}{3.395} & \multirow{4}{*}{0.025} \\
\hline & $6-10$ & 4.36 & 0.50 & & \\
\hline & $10-20$ & 4.37 & 0.81 & & \\
\hline & Over 20 & 4.53 & 0.64 & & \\
\hline
\end{tabular}

Source: Author's calculation based of SPSS 20.0

When it comes to significant differences in demographic variables, it can be concluded that there is a difference between men and women in relation to management, because the results of the study suggest that management includes more men in the decision making process. The analysis showed that women are statistically significantly less involved in decision making by the management. This is an important data, given the fact that women take a great part of the tourism employees. Although this issue does not belong to the focus of the conducted research, it is important to point out the necessity of gender equality for women and men employed in tourism, and to draw attention to the need for further and deeper research into the hierarchical structure of tourism employees in terms of gender and participation of women in decision making. Another important difference is salary satisfaction, where the younger population of employees is significantly dissatisfied with the salary (3.60) from other age categories of employees, especially from employees with the longest working experience (4.53). The population of employees with the least length of service or working experience is the least satisfied with the salary in comparison to other categories. Considering that, in comparison to other satisfaction factors, there are no statistically significant differences between the category of employees with the shortest working experience, it can be assumed that this factor does not play a decisive role in relation to the overall employee satisfaction.

When it comes to factors of tourist satisfaction with the quality of services in spa tourism, the most important ones were, above all, the service, professionalism and hospitality of employees (4.857), and then check-in at the desk reception (4.77) (see Table 4). This leads to the conclusion that the guests' first impression of the hotel is very important, but it is not less important to maintain positive emotions acquired during the first contact of the tourist with staff. 
Table 4. Factors of tourist satisfaction with the quality of services

\begin{tabular}{|l|c|c|c|c|c|}
\hline $\begin{array}{c}\text { Claims about factor of tourist } \\
\text { satisfaction with quality of service in } \\
\text { spa tourism }\end{array}$ & $\mathbf{N}$ & Min & Max & Mean & $\begin{array}{c}\text { Standard } \\
\text { deviation }\end{array}$ \\
\hline Check-in experience & 70 & 4.00 & 5.00 & $\mathbf{4 . 7 7 1 4}$ & .42294 \\
\hline Tidiness and cleanliness of the room & 70 & 4.00 & 5.00 & 4.6143 & .49028 \\
\hline Hotel restaurant & 70 & 4.00 & 5.00 & 4.6143 & .49028 \\
\hline Choice and quality of food & 70 & 4.00 & 5.00 & $\mathbf{4 . 5 8 5 7}$ & .49615 \\
\hline Wellness and spa treatments & 70 & 3.00 & 5.00 & 4.6429 & .53934 \\
\hline Tidiness and cleanliness of the hotel & 70 & 3.00 & 5.00 & 4.6143 & .51900 \\
\hline $\begin{array}{l}\text { Professionalism and hospitality of the } \\
\text { hotel employees }\end{array}$ & 70 & 4.00 & 5.00 & $\mathbf{4 . 8 5 7 1}$ & .35245 \\
\hline $\begin{array}{l}\text { Overall satisfaction with the quality of } \\
\text { services }\end{array}$ & 70 & 4.00 & 5.00 & 4.7429 & .44021 \\
\hline
\end{tabular}

Source: Author's calculation based of SPSS 20.0

Findings suggest the importance of selected factors of tourist satisfaction with quality of services in spa tourism. However, in Table 4., it can be seen that satisfaction with the choice and quality of food (4.58) is the lowest rated, that is tourists were least satisfied with the quality and choice of food in the hotels they stayed in, but it is important to note that this did not affect the overall satisfaction with the quality of the services provided (4.74). The obtained results are in accordance with the results obtained by Spinelli and Canavos (2000) who conducted their research in six hotels. There are no significant differences in the population of tourists by demographic variables in terms of satisfaction with the quality of services.

In further analysis of the key factors of tourist satisfaction with the quality of services, the table below shows the correlation between overall satisfaction with the quality of services and individual factors of service quality.

Table 5. Correlation of factors of tourist satisfaction with the quality of services with overall satisfaction with the quality of services

\begin{tabular}{|l|c|c|}
\hline \multirow{2}{*}{$\begin{array}{c}\text { Factors of tourist satisfaction with the } \\
\text { quality of services }\end{array}$} & \multicolumn{2}{c|}{$\begin{array}{c}\text { Overall satisfaction with the quality of } \\
\text { services }\end{array}$} \\
\cline { 2 - 3 } & $\begin{array}{c}\text { Pearson correlation } \\
\text { coefficient }\end{array}$ & $\begin{array}{c}\text { Statistical } \\
\text { significance }\end{array}$ \\
\hline Check-in expirience & 0.458 & 0.000 \\
\hline Tidiness and cleanliness of the room & 0.454 & 0.000 \\
\hline Hotel restaurant & $\mathbf{0 . 6 7 5}$ & 0.000 \\
\hline Choice and quality of food & 0.501 & 0.000 \\
\hline Wellness and spa treatments & 0.523 & 0.000 \\
\hline Tidiness and cleanliness of the hotel & 0.448 & 0.000 \\
\hline $\begin{array}{l}\text { Professionalism and hospitality of the hotel } \\
\text { employees }\end{array}$ & $\mathbf{0 . 6 0 0}$ & 0.000 \\
\hline Overall satisfaction with the quality of services & 1 & \\
\hline
\end{tabular}

Source: Author's calculation based of SPSS 20.0 
Based on these results it can be concluded that direct relationship, that is, professional and friendly communication is what tourists evaluated as the most positive and the most important factor, considering that staff courtesy, professionalism and hospitality are highly correlated with overall satisfaction with quality of services $(\mathrm{r}=.600)$. Furthermore, there is a very high positive correlation with the hotel restaurant $(\mathrm{r}=.675)$. It is interesting that this is the highest value of correlation obtained. A possible explanation should be sought in the fact that the hotel restaurant is part of the hotel which all guests can use on a daily basis, which is a very important part of the overall impression of tourists about the hotel and the quality of services which are provided. In accordance with this is the result about the service which was estimated at minimum of quality and that is quality and variety of food. In this sense, it can be recommended to the management of the hotel in spa tourism to improve the appearance, cleanliness and ambience of the hotel restaurant, as well as the quality and choice of food on the menu of the hotel restaurant, as one of the efficient ways of attracting tourists and improving the quality of service.

It is also important to identify the correlation and the impact of employee satisfaction on the quality of services and the satisfaction of the tourists with quality services in spa organizations.

Table 6. Correlation of factors of employee satisfaction with the overall tourist satisfaction with the quality of services

\begin{tabular}{|l|c|c|}
\hline \multirow{2}{*}{ Factors of the employees satisfaction } & \multicolumn{2}{c|}{$\begin{array}{c}\text { Overall satisfaction with the quality of } \\
\text { services }\end{array}$} \\
\cline { 2 - 3 } & $\begin{array}{c}\text { Pearson correlation } \\
\text { coefficient }\end{array}$ & $\begin{array}{c}\text { Statistical } \\
\text { significance }\end{array}$ \\
\hline Overall job satisfaction & 0.492 & 0.000 \\
\hline Reward system & 0.300 & 0.026 \\
\hline Salary satisfaction & 0.396 & 0.003 \\
\hline Satisfaction with the working environment & 0.483 & 0.000 \\
\hline Overall satisfaction with the quality of services & 1 & \\
\hline
\end{tabular}

Source: Author's calculation based of SPSS 20.0

As it can be seen in Table 6, employee satisfaction factors that significantly affect the overall tourist satisfaction with the quality of services are salaries and rewards, followed by the work environment. Well-paid workers who work have good working conditions present the basis for providing quality tourism services in spa tourism, and, in this way, lead to the satisfaction of tourists with the quality of services.

The most important finding of the research is related to the correlation between the employee satisfaction and the tourist satisfaction with the quality of the service in Lukovo spa, and important correlations have been identified that indicate the relation of the factor of employee satisfaction with the overall tourist satisfaction with the quality of services. This finding confirms the direct and positive impact of employee satisfaction on the tourist satisfaction with the quality of services. Employee satisfaction has a 
positive impact on the quality of the service, which directly affects tourist satisfaction with the quality of the provided services. In this sense, the results of this study are in accordance with the findings of previous studies in which researchers have also confirmed the impact of employee satisfaction on tourist or consumer satisfaction in the service sector in general (Chi, Gursoy, 2009; Harter, Schmidt, Hayes, 2002; Yee, Yeung, Cheng, 2008; Jung, Yoon, 2013; Spinelli, Canvos, 2000).

Besides the confirmation that employee satisfaction is related to customer satisfaction with the quality of services, it is important to note that the factors of reward system, salary satisfaction and satisfaction with the work environment and working conditions are statistically significantly correlated with the overall tourist satisfaction with the quality of services in spa tourism. Therefore, what makes the service a good quality service, and what motivates employees to be up to the task are in the first place of these three factors. This finding should not be taken literally, since other factors of employee satisfaction should not be ignored. However, as a key recommendation to human resources management in spa tourism, the need for effective policies regarding the rewarding system, improvement of the work environment and salaries of employees can be addressed in order to increase their motivation and satisfaction.

\section{Conclusions}

According to the results, all the tested hypotheses were confirmed which indicates a positive relationship between employee satisfaction and the quality of services, on the one hand, and between the employee satisfaction and the tourist satisfaction with the quality of services, on the other hand.

Apart from other factors influencing the choice of a particular tourist destination, a very important factor of the overall quality of service is communication and the attitude of employees towards the guests, because what is implied by the guest is that the service should be such as to enable favorable exploitation of the offered contents, from the beginning of the first contact at the reception desk to the use of various catering and tourist facilities offered contents. Communication with professional staff is the basis and it makes the image and provides the basic tone to the overall experience of spa tourism. Organizations in tourism industry cannot survive without the quality of tourism products. Moreover, the focus of quality of services in tourism is up to the employees. Therefore, it is of primary importance for the management of organizations in spa tourism to take care of their employees and to work on improving those factors that affect their dissatisfaction.

Based on the results of this research it can be said that it is important to pay attention to the working conditions and working environment of employees, relationships with the management, interpersonal relations in the collective, salary and reward system, as the main predictor of employee satisfaction in spa organizations. Also, when it comes to the category of the youngest employees and employees with shorter length of service, the most important factor of satisfaction in this category of employees is the salary, which is 
important information in terms of motivating young workers. Special recommendation to the management of organizations in spa tourism, but also to tourism in general, refers to the need for more intensive promotion of gender equality and equal participation of employees of both genders in decision making and cooperation with the management.

It is necessary to point out certain limitations of this research and to take into consideration that a small sample of respondents does not provide the basis for some general conclusions and only allows a partial insight into the relation of employee satisfaction and the tourist satisfaction with the quality of services in spa tourism. Therefore, one of the recommendations for further research may be the necessity for a broader research, relationship and impact of employee satisfaction on the tourist satisfaction with the quality of services in the organization of spa tourism, both in terms of sample size and the number of organizations involved. Finally, it would be important to examine whether this research relates only to the segment of tourists in spa tourism or whether the research can be applied to other forms of tourism. In other words, it can be examined whether the employee satisfaction in organizations will have the same impact on the quality of services and thus on the tourist satisfaction with the quality of services in other aspects of tourism. This would enable the design of a theoretical basis that would enhance the understanding of the importance and impact of employee satisfaction on the quality of services and the tourist satisfaction with the quality of services, which is still at a low level in our country.

In today's business environment, human resource management must take into account the fact that one of the imperatives for organizations is to identify the needs of their employees and to meet these needs in order to ensure that employees are satisfied and then realize the goals of the organization. It is of crucial importance to promote the policy of good human relationships, to involve employees in the decision making process, to give more responsibility to employees, but also to value the merits of the employees in order for them to gain full confidence in the management and achieve their potentials.

\section{Conflict of interests}

The authors declare no conflict of interest.

\section{References}

1. Bernhardt, K. L., Donthu, N., \& Kennett, P. A. (2000). A longitudinal analysis of satisfaction and profitability. Journal of business research, 47(2), 161-171, doi: 10.1016/S0148-2963(98)00042-3

2. Chi, C. G., \& Gursoy, D. (2009). Employee satisfaction, customer satisfaction, and financial performance: An empirical examination. International Journal of Hospitality Management, 28(2), 245-253, doi: 10.1016/j.ijhm.2008.08.003

3. Christen, M., Iyer, G., \& Soberman, D. (2006). Job satisfaction, job performance, and effort: A reexamination using agency theory. Journal of Marketing, 70(1), 137-150, doi: 10.1509/jmkg.2006.70.1.137 
4. Choi, T. Y., \& Chu, R. (2001). Determinants of hotel guests' satisfaction and repeat patronage in the Hong Kong hotel industry. International Journal of Hospitality Management, 20(3), 277-297, doi: 10.1016/S0278-4319(01)00006-8

5. Davis, K., \& Newstrom, J. W. (1989). Human behavior at work: Organizational behavior. McGraw-Hill, New York.

6. Drinić, D., Vranješ, M., \& Gašević, D. (2014). Consumer loyalty in retailing. Škola biznisa, (2), 91-106. [in Serbian: Drinić, D., Vranješ, M., \& Gašević, D. (2014). Koncept lojalnosti potrošača u prodaji].

7. Đokić, T., Pepur, M., \& Arnerić, J. (2015). The impact of employee satisfaction on customer satisfaction in financial services market. Economic Thought and Practice, (1), 49-79. [in Croatian: Đokić, T., Pepur, M., \& Arnerić, J. (2015). Utjecaj zadovoljstva zaposlenika na zadovoljstvo korisnika na tržištu financijskih usluga].

8. Grönroos, C. (1984). A service quality model and its marketing implications. European Journal of marketing, 18(4), 36-44, doi: 10.1108/ EUM0000000004784

9. González, M. E. A., Comesaña, L. R., \& Brea, J. A. F. (2007). Assessing tourist behavioral intentions through perceived service quality and customer satisfaction. Journal of business research, 60(2), 153-160, doi: 10.1016/j. jbusres.2006.10.014

10. Harter, J. K., Schmidt, F. L., \& Hayes, T. L. (2002). Business-unit-level relationship between employee satisfaction, employee engagement, and business outcomes: a meta-analysis. Journal of applied psychology, 87(2), 268.

11. Hunt, H. K. (Ed.). (1977). Conceptualization and measurement of consumer satisfaction and dissatisfaction (No. 77-103). Marketing Science Institute, Massachusets.

12. Jeon, H., \& Choi, B. (2012). The relationship between employee satisfaction and customer satisfaction. Journal of Services Marketing, 26(5), 332-341, doi: $10.1108 / 08876041211245236$

13. Jung, H. S., \& Yoon, H. H. (2013). Do employees' satisfied customers respond with an satisfactory relationship? The effects of employees' satisfaction on customers' satisfaction and loyalty in a family restaurant. International Journal of Hospitality Management, 34, 1-8, doi:10.1016/j.ijhm.2013.02.003

14. Koys, D. J. (2003). How the achievement of human-resources goals drives restaurant performance. Cornell Hotel and Restaurant Administration Quarterly, 44(1), 17-24, doi:10.1177/0010880403441002

15. Laškarin Ažić, M. (2017). The impact of hotel employee satisfaction on hospitability performance. Tourism and hospitality management, 23(1), 105117, doi: $10.20867 /$ thm.23.1.8 
16. Lawler, E. E., \& Porter, L. W. (1967). The effect of performance on job satisfaction. Industrial relations: A journal of Economy and Society, 7(1), 2028, doi: 10.1111/j.1468-232X.1967.tb01060.x

17. Lease, S. H. (1998). Annual review, 1993-1997: Work attitudes and outcomes. Journal of Vocational Behavior, 53(2), 154-183, doi: 10.1006/ jvbe.1998.1662

18. Locke, E. A. (1976). The nature and causes of job satisfaction. Handbook of industrial and organizational psichology. The nature and causes of job satisfaction: Handbook of industrial and organizational psichology, 1297-1349.

19. Miljković, S. (2007). Motivation of employees and behavior modification in health care organizations. Acta medica Medianae, 46(2), 53-62. [in Serbian: Miljković, S. (2007). Motivacija zaposlenih i modifikovanje ponašanja u zdravstvenim organizacijama].

20. Oliver, R. L. (1980). A cognitive model of the antecedents and consequences of satisfaction decisions. Journal of marketing research, 460-469, doi: $10.2307 / 3150499$

21. Pavlović, M., \& Marković, D. (2014). Theoretical approach to employee satisfaction and motivation. Vojno delo, 1, 289-302. [in Serbian: Павловић, M., \& Марковић, Д. (2014). Теоријски приступ задовољству послом и мотивацији запослених].

22. Perić, G., Gašić, M., Stojiljković, M., \& Ivanović, V. (2017). Perspectives of development of spa tourism in Serbia. Journal of Awareness, 2, 597-614.

23. Perić, G., Gašić, M., Ivanović, V., \& Stojiljković, M. (2015). Employee satisfaction in destinations of spa tourism in Serbia. Bizinfo (Blace), 6(2), 1-15. [in Serbian: Перић, Г., Гашић, М., Ивановић, В., \& Стојиљковић, М. (2015). Задовољство запослених у бањским туристичким дестинацијама Србије] doi: 10.5937/BIZINFO1502001P

24. Perić, G., (2014). Rewarding in order to increase satisfaction and motivation of employees in the spa tourism centers (Unpublished specialist's thesis). University of Belgrade, Faculty of Organisational Sciences, Belgrade. [in Serbian: Перић, Г., (2014). Награђивање у функцији повећања задовољства и мотивације запослених у бањским туристичким центрима].

25. Spinelli, M.A., \& Canavos, G. C. (2000). Investigating the Relationship between Employee Satisfaction and Guest Satisfaction. Cornell Hotel and Restaurant Administration Quarterly, 41(6), 29-33, doi: 10.1177/001088040004100604

26. Sageer, A., Rafat, S., \& Agarwal, P. (2012). Identification of variables affecting employee satisfaction and their impact on the organization. IOSR Journal of business and management, 5(1), 32-39.

27. Singh, J. K., \& Jain, M. (2013). A Study of employee's job satisfaction and its impact on their performance. Journal of Indian research, 1(4), 105-111. 
28. Statt, D. A. (2004). The Routledge dictionary of business management. Routledge Publishing, Detroit.

29. Schneider, B., \& Bowen, D. E. (1985). Employee and customer perceptions of service in banks: Replication and extension. Journal of applied Psychology, 70(3),

30. Sekulić, D., (2016). Quality in the function of providing satisfaction of the hotel service users (Unpublished doctoral dissertation). University of Kragujevac, Faculty of Economics, Kragujevac. . [in Serbian: Секулић, Д., (2016). Квалитет у функцији обезбеђивања сатисфакције корисника хотелијерских услуга].

31. Topalović, S., (2013). State and prospects of spa tourism in Serbia . Globus, 37, 38, 123-134. [in Serbian: Топаловић, С., (2013). Стање и перспективе бањског туризма у Србији].

32. Vrtiprah, V., \& Sladoljev, J. (2012). The impact of employee satisfaction on the qualuty of products and service in the hotel company. Economic Thought and Practice, 21(1), 97. [in Croatian: Vrtiprah, V., \& Sladoljev, J. (2012). Utjecaj zadovoljstva zaposlenika na kvalitetu proizvoda i usluga u hotelskom poduzecu].

33. Wangenheim, F. V., Evanschitzky, H., \& Wunderlich, M. (2007). Does the employee-customer satisfaction link hold for all employee groups?. Journal of Business Research, 60(7), 690-697,doi: 10.1016/j.jbusres.2007.02.019

34. Yee, R. W., Yeung, A. C., \& Cheng, T. E. (2008). The impact of employee satisfaction on quality and profitability in high-contact service industries. Journal of operations management, 26(5), 651-668, doi: 10.1016/j.jom.2008.01.001

35. UNWTO, (2011). Master plan of sustainable rural tourism in Serbia. [in Serbian: UNWTO (2011). Мастер план одрживог развоја руралног туризма у Србији], https://futurehospitalityleaders.files.wordpress.com/2012/11/masterplan-odrzivog-razvoja-ruralnog-turizma-u-srbiji.pdf (December 24, 2017). 